\title{
Inactive cardiac sarcoidosis with characteristic findings on cardiac MRI
}

\author{
Yusuke S Hori, Satoshi Kodera, Hiroto Oshima, Junji Kanda
}

Asahi General Hospital, Asahi, Chiba, Japan

\section{Correspondence to}

Dr Yusuke S Hori,

ys-hori@umin.ac.jp

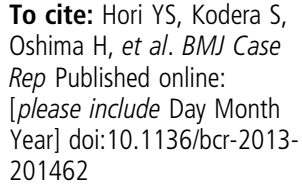

\section{DESCRIPTION}

Sarcoidosis has an active inflammatory phase and an inactive fibrotic phase. 18F-fluorodeoxyglucose positron emission tomography (FDG-PET) and gallium $(67 \mathrm{Ga})$ scintigraphy are known to be useful for detecting its active phase ${ }^{1}$ but not its inactive phase. Delayed enhancement with gadolinium during cardiac MRI is a useful modality for detecting cardiac sarcoidosis ${ }^{2}$ and can reveal inactive fibrotic lesions. ${ }^{3}$ In this case, a 66-year-old woman had gradually decreased her ejection fraction $(<50 \%)$ with regional dyskinesia on echocardiography after her initial heart failure. Cardiac sarcoidosis had been suspected, but ACE assays were negative at follow-up visits. Her admission was for another episode of heart failure. ACE, FDG-PET and $67 \mathrm{Ga}$ scintigraphy results were negative. On cardiac MRI, however, she had characteristic findings of cardiac sarcoidosis, including transmuraldelayed anteroseptal enhancement, midwall-delayed inferoseptal enhancement and subepicardial-

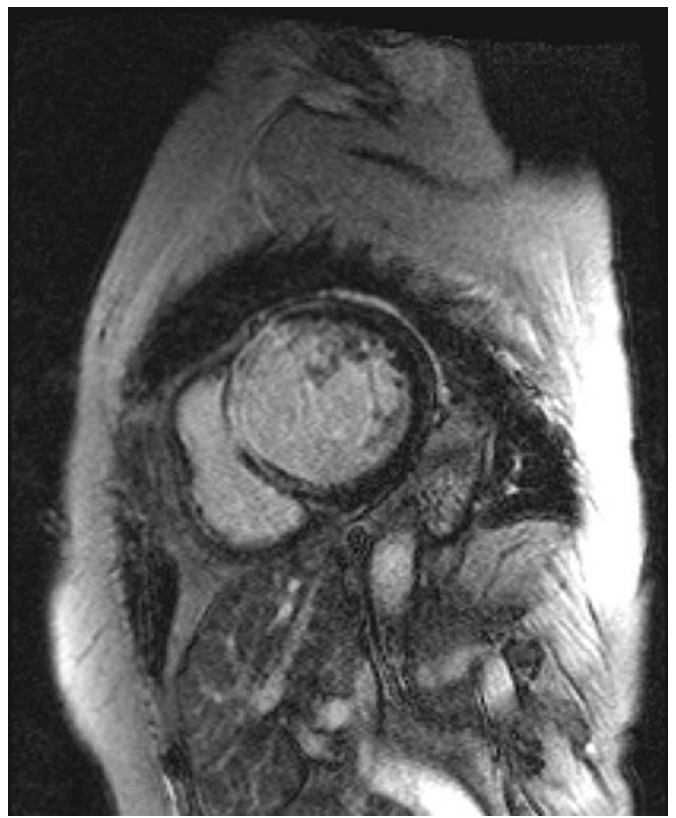

Figure 1 Cardiac MRI with gadolinium showing characteristic findings of cardiac sarcoidosis: transmural-delayed enhancement in anteroseptal wall, midwall-delayed enhancement in inferoseptal wall and subepicardial-delayed enhancement in anterior and lateral wall. delayed anterior and lateral wall enhancement (figure 1), with septal dyskinesia. Bilateral lymphadenopathy, purified protein derivative skin test and superficial cervical lymphadenopathy confirmed the presence of cardiac sarcoidosis. For differential diagnoses, dilated cardiomyopathy is not commonly associated with delayed subepicardial and lateral wall enhancement. Myocardial infarction and myocarditis are less likely. Subendocardial sparing is not seen in myocardial infarction, and the affected areas do not correspond with coronary territories. There were no inflammatory findings such as fever or elevated $\mathrm{C}$ reactive protein. Earlier cardiac MRI might have led to earlier treatment and prevention of disease progression. We conclude that once cardiac sarcoidosis is suspected, cardiac MRI should be considered, as it has a sensitivity of nearly $100 \%$. $^{2}$

\section{Learning points}

- Cardiac MRI is a useful modality for detecting the inactive phase of cardiac sarcoidosis.

- Patients with positive results require careful follow-up.

- Negative results for common tests such as an ACE assay and gallium scintigraphy should not be allowed to rule out cardiac sarcoidosis.

Acknowledgements We would like to thank Dr Nanae Sato, Dr Hiroki Suzuki, Dr Kazutoshi Sato and Dr Atsushi Kuno for their kind advice and encouragement in the preparation of this manuscript.

Contributors YSH wrote the manuscript, and SK, HO and JK critically reviewed it.

Competing interests None.

Patient consent Obtained.

Provenance and peer review Not commissioned; externally peer reviewed.

\section{REFERENCES}

1 Okumura W, Iwasaki T, Toyama T, et al. Usefulness of fasting 18F-FDG PET in identification of cardiac sarcoidosis. J Nucl Med 2004:45:1989-98.

2 Smedema JP, Snoep G, van Kroonenburgh MP, et al. Evaluation of the accuracy of gadolinium-enhanced cardiovascular magnetic resonance in the diagnosis of cardiac sarcoidosis. J Am Coll Cardiol 2005;45:1683-90.

3 Iles L, Pfluger H, Phrommintikul A, et al. Evaluation of diffuse myocardial fibrosis in heart failure with cardiac magnetic resonance contrast-enhanced T1 mapping. J Am Coll Cardiol 2008:52:1574-80. 
Copyright 2013 BMJ Publishing Group. All rights reserved. For permission to reuse any of this content visit http://group.bmj.com/group/rights-licensing/permissions.

BMJ Case Report Fellows may re-use this article for personal use and teaching without any further permission.

Become a Fellow of BMJ Case Reports today and you can:

- Submit as many cases as you like

- Enjoy fast sympathetic peer review and rapid publication of accepted articles

- Access all the published articles

- Re-use any of the published material for personal use and teaching without further permission

For information on Institutional Fellowships contact consortiasales@bmjgroup.com

Visit casereports.bmj.com for more articles like this and to become a Fellow 